\title{
The quarry proposed by the St. Marys Cement Inc. for a location near Carlisle, Ontario, should not be permitted: Adjudication Report
}

\author{
Vanessa Chaimbrone, Peggy Cheng, Meagan Coughlin, \\ Nigel Gale, Melissa Hurst, Victoria Robson
}

This study was conducted under the supervision of Professor Glenn Fox, Food, Agricultural and Resource Economics, Ontario Agricultural College

University of Guelph, Guelph, Ontario, Canada

\begin{abstract}
Arguments were presented in opposition to and in favour of St. Marys Cement Inc.'s proposal to construct a limestone quarry near Flamborough, Ontario as written reports and oral debates. This paper describes the development and implementation of a set of decision-making criteria that is used select the stronger of the two opinions. Measures were taken to limit bias in the adjudication process, maintain a high quality of referenced information, and establish a fair, comprehensive set of standards necessary for a convincing argument before the opposing arguments were presented. According to this set of decision-making criteria, the Opponents' argument in opposition to the movement against development of the quarry was deemed most convincing. Although both parties structured arguments on social, economic, and environmental grounds, the arguments of the Opponents were stronger overall. Construction of the quarry is legal, and should be permitted as a benefit to the province of Ontario.
\end{abstract}

$\mathrm{T}$ he adjudicators met prior to the disputes to create criteria that would be used to assess the content of the presentation, the cross-examination, and the brief. At the time, we acknowledged potential for bias stemming from personal beliefs, education, and employment. An evaluation process was designed to eliminate partiality towards either the proponents or opponents. The process first considers the legality of the proposed action (i.e. action to permit quarry, action to deny quarry). Second, the arguments presented by the parties are compared to determine whether the existing law increases the welfare of society in terms of economic, environmental, and health benefits.

\section{ACCEPTABLE INFORMATION AND BIAS}

The criteria used in this debate evolved from legal, environmental and health concerns. We have reviewed each party's sources for accuracy and bias. Statements that are untrue or from biased sources were not simply ignored; they were counted against the party that made them. We accepted statements from corporate and advocacy groups on both sides of the argument. However, to maintain community and corporate accountability, the context of each statement was investigated during review of both parties' sources. Prior to the dispute the adjudicators decided that local Flamborough opinion surveys would not be accepted due to concerns that respondents might overstate or understate preference in attempts to skew survey outcomes to suit bias. We did not resolutely select a preferred property rights structure, and have acknowledged that bias may skew our personal preferences towards a certain property structure. Instead, if a party claims that their argument is justified because it follows a specific property rights structure, they must provide a convincing argument for the use of the structure. We also want to acknowledge that the debate is site-specific. Proposition of a new site is a new argument, and therefore any new proposed location will not be considered.

\section{THE LAW}

\section{Legal Criteria}

In a democratic society, laws are generally just because they reflect the principles of the people. A just law exists to increase the wellbeing of the people (not only the benefit of "the greater good", but also the benefit of minorities). However, a law can be amended as norms and mores change, or if the law is proven unjust. Because of this potential for legal amendment, legality is not a sufficient condition for a convincing argument. 
Therefore if one party proves that the opposing party presents an action that is against existing laws, we will not necessarily discount the illegal argument completely. It is then the responsibility of the party presenting the illegal action to convince us that the law to be broken is unjust (that abiding by the law will not increase the wellbeing of society).

\section{Arguments and the Law}

Neither party clearly explains where St Marys Flamborough Quarry falls under the current context of the law. The proponents state, "a Ministerial Zoning Order in April 2010 put a freeze on the allowable land use for the Flamborough site." While both parties state that the current land use under the freeze is for agriculture and conservation management, they interpret the potential uses of the land differently. The opponents state that "aggregate extraction is an approved and recognized land use", whereas the proponents state that under the Ontario Aggregate Resources Act "aggregate extraction is not permitted." To determine the legal standing of the quarry, we consulted the proponents' reference to the 1990 Ontario Aggregate Resources Act. It appears that the proponents have misinterpreted the Act. Regarding aggregate extraction under agriculture and conservation management land:

"In considering whether a licence should be issued or refused, the Minister or the Board, as the case may be, shall have regard to,

(a) the effect of the operation of the pit or quarry on the environment; ...

(f) any possible effects of the operation of the pit or quarry on agricultural resources;",

As shown above, the Act states that the Minister must "consider" whether a proposed extraction project poses significant environmental or agricultural risks. This is not the same thing as prohibiting aggregate extraction outright. It implies that the decision is made with the Minister or the Board's discretion as to whether the risks of a proposed project are outweighed by the benefits. Although a section of the act prohibits aggregate extraction in areas that are not zoned for it, the quotation shows that there are legal grounds for appeals to the zoning by-law. According to the act, it appears that aggregate extraction is not illegal at the Flamborough site. According to our criteria, it is necessary for the proponents to explain why the quarry should not be permitted (that abiding by the law that permits the quarry will decrease the wellbeing of society).

\section{The Economics of the St. Mary's Cement INC.}

\section{Economic Analysis Criteria}

We chose to accept cost-benefit analysis as a measure of welfare. Although it is not the only measure of value, dollar valuation is no less valid than other human measurement constructs (i.e. time, distance, development indices, etc.).

\section{Economic Arguments}

Opponents and proponents use similar data to arrive at different present costs and benefits. The opponents consider dollars accruing to the province and to community infrastructure to be a cost, whereas proponents consider dollars accruing to the province a benefit. These are both valid conclusions depending upon the chosen property rights perspective. The proponents reference trespass and nuisance (suggesting a Traditional Liberal perspective) but do not explicitly state why the use of this perspective is justified. In addition, the proponents include a valid argument that there is a negative relationship between proximity to a quarry and local property values. The opponents reference and defend a Utilitarian property rights perspective (section 3.0).

The opponents suggest that FORCE has imposed a deadweight loss to society by imposing excessive compliance costs on St. Marys Cement Inc.'s bid to entering the market. Although St. Marys Cement Inc. has complied with all impact testing, FORCE has appealed to introduce stricter environmental regulation. The opponents provide a convincing argument that this is an attempt to increase costs for St. Marys Cement Inc. rather than providing persuasive reasons why the quarry should not exist. If FORCE's actions are accepted, it could set a precedent for more wasteful compliance spending in the future.

We conclude that although the proponents present a convincing argument for decreasing property value, the opponents excel. The opponents present a well-constructed cost-benefit analysis aligned with a justified property rights perspective, and include long-term considerations for efficient provincial spending that minimize dead-weight loss.

\section{ENVIRONMENTAL FACTORS}

\section{Environmental and Health Criteria}

Because rights and values are human constructs, they can only be applied to a feature if one party is human. We therefore chose to examine environmental arguments from an anthropogenic perspective, as they benefit humans. A human perspective is needed to give meaning to the environment through those rights and values we hold toward it, rather than any "intrinsic" value the environment holds itself. We acknowledge that humans benefit from the environment in many ways, and include use and non-use benefits. Humans also benefit from sound physical and psychological health.

\section{Environmental and Health Arguments}

Both parties addressed potential environmental impacts of the quarry. The proponents argue that the quarry would damage cool-water fisheries and biodiversity in a species-atrisk area. However, neither the brief prepared by the proponents nor Hindley discuss whether this fishery is significant to human benefit. Because the proponents fail to 
acknowledge why we should value biodiversity or the fisheries beyond intrinsic value, arguments in favor of fisheries and biodiversity do not satisfy criteria for a strong environmental argument.

The proponents' argument that detriment to ground water will have unacceptable impact on the health and wellbeing of Flamborough residents is much stronger. They anticipate the opponents' proposed groundwater recirculation solution, and explain why it is not reliable. The opponents', however, discredit this argument by recounting the considerable measures St. Marys Cement Inc. has enacted to protect local groundwater. Furthermore, because St. Marys Cement Inc. is very likely to follow the precautionary guidelines in place for the entire aggregate industry, much environmental harm would be avoided. The opponents present a very convincing argument that the members of FORCE block or reject St. Marys' environmental precautions due to NIMBY-ism, rather than genuine concern for environmental welfare.

\section{CONCLUSION}

According to the Ontario Aggregate Resources Act, construction of a quarry at the Flamborough site is not illegal. As described above, the opponents present convincing arguments that by following the law, the welfare of society will be unchanged or improved. The proponents did not create a convincing case that following the law would significantly decrease the welfare of society. Because there is no reason to amend the law that permits the quarry on the basis of social welfare (as determined by economic, environmental, and health benefits), we conclude that the opponents' case is the winner. Construction of the Flamborough quarry should be permitted. 